Information for citation:

Mikhailova N. S., Vakhitova Yu. I. Rezhisser-postanovshchik kak sub"ekt intellektual'nykh prav: problemy opredeleniya statusa [The Stage Director as a Subject of Intellectual Property Rights: Problems of the Status Determination] Vestnik Permskogo Universiteta. Juridicheskie Nauki - Perm University Herald. Juridical Sciences. 2017. Issue 38. Pp. 497-507. (In Russ.). DOI: 10.17072/1995-4190-2017-38-497-507.

UDC 347.786

DOI: 10.17072/1995-4190-2017-38-497-507

\title{
THE STAGE DIRECTOR AS A SUBJECT OF INTELLECTUAL PROPERTY RIGHTS: PROBLEMS OF THE STATUS DETERMINATION
}

\author{
N. S. Mikhailova \\ Perm State University \\ 15, Bukireva st., Perm, 614990, Russia \\ ORCID: 0000-002-3907-0183 \\ ResearcherID: 0-5808-2017 \\ e-mail: natalya-mikhailova@yandex.ru
}

\section{Yu. I. Vakhitova}

Higher School of Economics (Perm)

38, Studencheskaya st., Perm, 614046, Russia

ORCID: 0000-0002-5022-0402

ResearcherID: O-4175-2016

Articles in DB "Scopus" / "Web of Science":

DOI: 10.17072/1995-4190-2015-2-41-48

e-mail: julvakhitova@gmail.com

Introduction: the article considers the status of the stage director as a holder of neighboring rights to performance. For an appreciable length of time, the question of the nature of the director's rights to a theatrical performance was controversial in national civil law. To a large extent, this situation is due to the fact that a director of an audiovisual work, unlike a stage director, has a copyright. In both cases, the nature of the directors' work is recognized as creative; however, the absence of an objective form of the intellectual activity result makes it impossible to recognize the copyright of the theatre director to a performance. The legislator introduced a block of amendments to Chapter 71 of the Civil Code of the Russian Federation directed at increasing protection of the stage director's related rights. In this regard, the analysis of doctrinal views and legislative constructions regulating directorial activity is deemed to be currently important. Purpose: to define the legal status of the theatrical performance director as compared to other performers specified in Article 1313 of the Civil Code of the Russian Federation. Methods: the methodological framework of the research is based on the comparativehistorical, analytical and system methods. Results: as the analysis has shown, in Russia there are no legal reasons for endowing the stage director of a theatrical performance with the status of the author, because the result of his work is not objectified. At the same time, the theatre director possesses a number of features different from those of performers and conductors, therefore his rights need an increased protection. Conclusions: the stage director holds a special place in the system of performers. That is why the national legislator's orientation towards strengthening the protection of directors' neighboring rights should be deemed appropriate. However, there are still some issues that require detailed legislative regulation.

Keywords: stage director; theatrical performance; audiovisual work; result of intellectual activity; performance; object of copyright; single creative concept; a complex object

(C) Mikhailova N. S., Vakhitova Yu. I., 2017 


\section{Information in Russian}

\section{РЕЖИССЕР-ПОСТАНОВЩИК \\ КАК СУБЪЕКТ ИНТЕЛЛЕКТУАЛЬНЫХ ПРАВ: ПРОБЛЕМЫ ОПРЕДЕЛЕНИЯ СТАТУСА}

\section{Н. С. Михайлова}

Кандидат юридических наук, доцент кафедры гражданского права

Пермский государственный национальный исследовательский университет

614990, Россия, г. Пермь, ул. Букирева, 15

ORCID: 0000-002-3907-0183

ResearcherID: $0-5808-2017$

e-mail: natalya-mikhailova@yandex.ru

\section{Ю. И. Вахитова}

Старший преподаватель кафедры гражданского и предпринимательского права Национальный исследовательский университет «Высшая школа экономики» (Пермь) 614046, Россия, г. Пермь, ул. Студенческая, 38

ORCID: 0000-0002-5022-0402

ResearcherID: O-4175-2016

Статьи в БД «Scopus» / «Web of Science»:

DOI: 10.17072/1995-4190-2015-2-41-48

e-mail: julvakhitova@gmail.com

Введение: настоящая статья посвящена изучению статуса режиссера-постановщика как обладателя смежного права на исполнение. В течение длительного периода времени для отечественной циивлистики вопрос о характере прав режиссера на театрально-зрелищное представление был дискуссионным. Во многом данная ситуаџия обусловлена тем, что режсиссер-постановщик аудиовизуального произведения обладает авторским правом. Однако театральный режиссер признается лишь субъектом смежного права. Характер деятельности режиссеров в обоих случаях признается творческим, но отсутствие объективной формы выражения результата интеллектуальной деятельности становится причиной, по которой невозможно признать авторство театрального режиссера на постановку. Законодателем был принят блок правок в главу 71 Гражданского кодекса РФ, направленных на усиление охраны смежных прав режсссера. В этой связи анализ доктринальных воззрений и законодательных конструкций, регламентирующих режиссерскую деятельность, представляется актуальным. Цель: выявить особенности правового статуса режиссера театрального представления среди других исполнителей, указанных в ст. 1313 ГК РФ. Методы: сравнительно-исторический, аналитический и системный методы. Результаты: анализ доктринальных воззрений и законодательных конструкций показал, что в России отсутствуют правовые основания для признания за режиссером-постановщиком театрально-зрелищного представления статуса автора, поскольку результат его труда не объективизирован. Вместе с тем театральный режиссер имеет ряд особенностей, в отличие от артистов-исполнителей и дирижеров, ввиду чего права данного субъекта нуждаются в эффективных механизмах защитыл. Выводы: режиссер-постановщик театрально-зрелищного представления занимает особое место в системе исполнителей. Именно поэтому нацеленность отечественного законодателя на усиление охраны смежных прав режиссеров заслуживает положительной оценки. Однако ряд принципиальных вопросов по-прежнему нуждаются в детальной законодательной регламентации.

Ключевые слова: режиссер-постановщик; театрально-зрелищное представление; аудиовизуальное произведение; результат интеллектуальной деятельности; исполнение; объект авторского права; единый творческий замысел; сложный объект 


\section{Introduction}

The current edition of the RF Civil Code mentions the stage director twice: as the author of the audiovisual work (Article 1263) and as the holder of neighboring rights to the performance (Article 1313). In the first case, the stage director is granted with personal non-property rights and the exclusive right in its fullest extent, since by virtue of express reference by Item 2 of Article 1263 of the RF Civil Code, the director, together with the author of the script and the composer, is the author of the audiovisual work. In the second case, the stage director, together with the artists and the conductor, has the status of the performer. In spite of the fact that the result of the director's work is acknowledged as artistic, Chapter 71 of the RF Civil Code significantly mitigates the right of use and deprives the director of the effective mechanisms for protection of his right.

For a long time, domestic civil science has been developing the concept of the theatrical performance and the variants of providing the stage director with the proper means of his rights protection. The discussions, which existed as far back as in Soviet times, on pages of the Soviet juridical literature, have not been finished until today: scientists draw a parallel between the statuses of the two directors and study the variants of strengthening the positions of the theatrical director.

A special meaning was assigned to the problem with a legislative initiative aimed at extending the exclusive right and personal non-property rights of the director of a theatrical production, and associated with amending of Chapter 71 of the RF Civil Code. A complex of amendments that will come into force on January 1, 2018 ${ }^{1}$ will significantly change the result of the director's creative work. For this reason, a comparative analysis of the scientific concepts and of the legislative approach to the regulation of the status of the theatrical performance director appears to be currently important.

\section{Stage Director in the System of the Theatrical Production Performers}

Article 1313 of the RF Civil Code provides a list of performers: actors, conductors, and directors as holders of neighboring rights to the results of the intellectual activity - the performance. For a long

\footnotetext{
${ }^{1}$ About Introducing Changers into Part Four of the Russian Federation Civil Code: Federal Law of the Russian Federation No. 43-FZ dd March 28, 2017. [Electronic resource]. Accessed from reference legal system "ConsultantPlus".
}

period of time, the result of the artistic work of performers had not been regulated, as it was not acknowledged as reproducible. The civil law science had a task of searching for an optimal construction that would protect the instantaneous creative act. The positions of civil scientists were focused on three modules: granting the performers with the copyright to the separate product created by them; granting the copyright to the derivative product that appears as a result of the main product adaptation; acknowledging the performers to be the subjects of special rights which are close to copyright but differ from it in their content.

The system of copyright was reasonably considered non-applicable because the performers do not make a new product but change the exterior form of the already existing one. In spite of the fact that many products became recognizable thanks to the innovatory interpretation of the performers, in this case, as E.P. Gavrilov was right to say, the new form was "built up" over the already existing object [4, p. 57].

As for the second module, at first sight some elements are found in the activities of the performers that resemble those in the derivative product: in both cases, a separate object is taken as a basis, the object appears as a result of the creative work, the protection of the new result of labor directly depends on the protection of the author's rights. However, the main difference between the derivative product and the performers' activities seems to be in the object of protection. In case of the derivative product, the object of protection is "a complex of ideas, thoughts and images" [17, p. 32], which is built based on the existing creative result, while in case of performing it is the creative act itself that goes under protection.

Nowadays, Russian legislation also proceeds from the idea that the performer gives a new form to the product protected by copyright, and does not affect the form of the author's product. The performer obtains an independent right exclusively to the result of his own performance.

As V. A. Dozortzev noted, due to the technological development, there appeared a new result of creative work with the form being of priority importance, protected beyond the scope of the copyright $[8$, p. 16]. Invention of sound-recording devices allowed for the establishment of the optimal model of the new rights that "neighbor" the copyright, and for the legislative regulation of the performing activities. Impossibility to provide protection for 
performers has always been associated with the difficulties in objectification of their labor results, while the artistic nature of this activity has never been put in doubt. The system of neighboring rights made it possible to distinguish between the results of the author's work and the results of the performer's work, giving protection to both.

At the same time, the protection of the performer's activities in many ways differ from copyright. Copyright is characterized with the protection which does not depend on the accessibility to the indefinite range of persons and way of fixation [8, p. 12]. Protection of the performers' rights is provided with the account for these circumstances.

The share of the contribution made by artists is beyond the limits of the original product and involves the chosen way of presenting the original product to the public. For this reason, we think that the complex of rights given in Article 1315 of the RF Civil Code is sufficient for protecting the interests of the artist-performer and the conductor. The protection is provided for the creative act itself, represented by each separate performance.

As D. Liptzik rightfully mentioned, if one product is several times represented via live performance, then the use of one product takes place, and the neighboring right objects arise in number that equals the number of performances, because performance is an ephemeral act [16, pp. 323-324]. Therefore, each subsequent performance of the same product by the performer will be a new and independent neighboring right object, which means that each performance is protected separately. Thus, the subsequent performances are protected and used regardless of the status of rights to the previous performances.

In the juridical literature, a detailed analysis has been made of the features of performance: interpretation inseparable from the production character [1, pp. 50-53] (some of scientists diagnosed the "death" of the staging in the actor's work), availability of the original source in the form of the author's product, instantaneous character and protection of each performance separately [4, p. 123].

Regulation of the theatrical production as an object of neighboring right complies with the international trends in this sphere. The World Intellectual Property Organization's contract (in which Russia is a participant) refers the theatrical production to performance, and performers are understood as actors, singers, musicians, dancers and other individuals who play roles, sing, read, declaim, play musical instruments or in any other way express literary or artistic work or folklore works ${ }^{1}$.

The special feature of a theatrical production performers is that they are intermediaries between the direct authors (for example, of a literary text) and the audience. Their activity is of an instantaneous nature. The performer, similar to the author, is an artistic unit, and in this respect the RF Civil Code uses the term "performer" as a synonym to the term "author of the performance" ("author of the execution") [2, p. 118].

In order to get a new result, the artistperformer and the conductor need to personally participate in the artistic act. By contrast with them, the stage director of the play does not personally participate in the show. The director's activity is a complex one and is aimed at creating a single artistic concept of the play. The specificity of a theatrical production is in the presence of the uniting director's idea. Thus, the activities of the subject responsible for the entirety of the performance symphony, i. e. of the stage director, requires a detailed study.

\section{Specific Features of the Theatrical Production Director}

It appears that in Russia the status of the theatre director defined in the RF Civil Code depends on two aspects: the culturological and legal ones. The specific historical features of the theatre business development in Russia were the reason why special rights were never granted to the stage director.

Till the end of the $19^{\text {th }}$ century, the stage director in a Russian theatre functioned as the chief administrator and was responsible for issues that accompany the creative work but do not mediate it. A theatrical production representing a complex of artistically whole images was not typical of the theatre of the period in question. Spectacular organizations were the theatres of the actor and of the playwright.

The theory and history of arts uses the term "actor's stage direction" in respect of the above period

\footnotetext{
${ }^{1}$ Contract of WIPO on Performances and Phonograms dd December 20, 1996. [Electronic resource]. Accesses from reference legal system "ConsultantPlus".
} 
$[11$, p. 370]: the most talented actor of the troupe managed the performance and scene rehearsals. This allows us to emphasize the role of an individual in the Russian theatre development.

However, starting from the "theatre revolution" of the late $19^{\text {th }}$ century, associated with the activities of V. I. Nemirovich-Danchenko and K. S. Stanislavsky, the actor's and the author's leading role in the theatre was rejected. The innovations were preceded by the crisis in theatre business. After overcoming the crisis, the spectacular organization of the new type was created, and the position of the stage director was reinforced, first - as the artistic manager of the troupe, and subsequently - as the subject coordinating the creative component of the production.

The introduced artistic wholeness of the performance reasonably raised the stage director to the level of the first among equals as compared to other performers. A tremendous contribution to researching the specific features of the stage director's activities was made by Soviet civil scientists. In the majority of cases, they put the stage director status dependent on the position of the object (theatrical production) itself.

For example, M. V. Gordon underlined the impropriety of scientists' conclusions about the results of creative work of a choreographic product's author [5, p. 232]: the subject of protection are the instructions concerning the performance, given in writing or in some other objective form. That is why the director's work is the object of copyright not in the form of performance but in the form of literary writings having a special purpose of supporting the arrangement of performance on the stage.

B. S. Antimonov and E. A. Fleishits [1, p. 57] justly noted that a specific creative character of the director's work during the performance preparation results in difficulties when defining the nature of the right.

$\mathrm{V}$. Ya. Ionas thought that the only way for a director to reach the acknowledgement of his authorship was to work creatively with the literary text and develop a unique script [10, p. 152]. With this, it is necessary to keep in mind that technical remarks and a plan of scenes embedded mechanically into the literary text do not provide an opportunity to claim for authorship.

V. I. Serebrovsky believed that the object of copyright is exceptionally the director's (working) script, representing a creative adaptation of the literary script by the director $[18$, p. 57]. For this reason, the scientist insisted on recognizing the copyright of the film director: his personal script and creative work are "kept" unchanged on the film strip.

Judging from the above specific features of the director's work, we think that the aim of this work is not in the mechanical but in the constructive, creative effort during the performance preparation. The expected question is: do we have an opportunity to make a conclusion that a director creates a so called "theatrical product", and are the researchers right to believe that the director gets a copyright to the theatrical performance as a whole? The representatives of the modern scientific community express completely different opinions about that.

S. S. Alekseev came up with some sound arguments to defend the position that the term "performer" is used in a generalized sense. For example, a director of the show does not straightforwardly participate in the performance, the participation of a conductor in the musical performance is also very specific, but nevertheless, legislatively they have the same status [12, p. 578].

S. P. Grishaev thinks that the activity of a stage director is a creative work, and a theatrical show meets the criteria of the product protected by copyright, and thus one could speak about the copyright protection of the director's activities. In A. P. Grishaev's opinion, theatrical shows are often video-taped, and so they automatically become audiovisual products, and correspondingly, the directors of these performances become the objects of copyright [7].

It is often that a performance has a direct connection with the products protected by copyright. In this case, the link between the performance and the copyright, and their "neighborship" are manifested: the performer acts as an intermediary, an intermediate link between the author and the listener (viewer).

E. A. Morgunova, when studying the above problem, states that in modern conditions, there are a lot of reasons for treating a theatrical show as a separate product, and correspondingly - as an object of copyright. At the same time, the author thinks that the conclusive answer to the question about whether a performance is an object of copyright 
should be given by experts in performing arts, and the legislator is to define the legal regime of the performance on the basis of their conclusion [14]. It is difficult to agree with this point of view. In our opinion, the criteria of distinction between the director's copyright and neighboring right should be established legislatively depending on the object created by him.

The difference between the staging and theatrical products is in the fact that the creative work of the director is inseparable from the act of production [1, p. 114]. The legislative approach to a theatrical production as a complex object of intellectual rights significantly changes the essential features of these objects and builds a new system of distinguishing between the rights of the organizer, initial authors and performers. This object is complex because it accumulates several results of the intellectual activity, and it is the director who is to perform the main function - i. e. the creation of the single artistic conception.

The creative work of stage directors differs noticeably from the work of actors-performers and resembles the work of film directors in many respects. There was an active discussion of civil scientists about stage directors who should get copyrights to their stagings, just like film directors are considered to be the authors of the film. In the opinion of a number of researchers, exceptionally for the purpose of the unified terminology, the stage director is also called "a performer" in Article 1313 of the RF Civil Code, and the staging, which is the object of his right, is called "a performance" [13, p. 589].

\section{Audiovisual Work Director and Theatrical Production Director: Correlation of the Obtained Creative Result}

Article 14bis of the Berne Convention ${ }^{1}$ establishes that defining the circle of authors of a cinema product is within cognizance of the national legislator in the country where the protection is needed. Item 2 of Article 1263 of the RF Civil Code establishes the so-called "triumvirate" of the authors: the director-producer, the author of the screenplay and the composer, who is the author of the specially

\footnotetext{
${ }^{1}$ The Berne Convention for the Protection of Literary and Artistic Works dd September 9, 1886. [Electronic resource]. Accessed from reference-legal system "ConsultantPlus".
}

created musical work. The general provisions about intellectual rights in Item 4 of Article 1228 of the RF Civil Code include the rule that the rights to a result created by joint creative work of some persons belong to the co-authors jointly.

Civil scientists repeatedly underlined that, besides the tree mentioned authors, other individuals participate in the film-making process (for example, operators, artistic directors). According to provisions of Article 1263 of the RF Civil Code, they have exclusive right to their product, except cases when the exclusive right is transferred to another person under the contract.

At the same time, by implication of Article 1263 of the RF Civil Code, the mentioned individuals are not the authors of the audiovisual product wholly as A. P. Sergeev was right to say, that is a specific feature of an audiovisual object. Consequently, the above example of the distribution of rights between the authors of original products that are components of an audiovisual product refers to co-authorship not by virtue of the joint creative activities but by the explicit reference of law [13, p. 599].

Besides the two categories of the authors (those having right to an audiovisual object as a whole, and those having right to its elements), one also has to distinguish holders of right to other results of intellectual activity, for example, authorsperformers, whose activities are also included into the complicated object of rights.

In the juridical literature, the attention is often given to the fact that a stage director is the "first among equals" compared to authors of the audiovisual product set by law. He manages staging and acting, he is the key figure to organize and lead the artistic process of creating the audiovisual product [13, p. 299].

The mentioned features of the stage director's activity seem to condition the circumstance due to which in a number of foreign countries the law acknowledges the inseparability of the cinematographic product components (Germany), and, nevertheless, the stage director is always among the authors. In other cases, authorship is recognized as belonging to either the producer (mainly, in the Anglo-American system), or jointly to the producer and the director (in the United Kingdom, in respect of the films created after July 1, 1994) [15, p. 21]. 
Giving arguments to support the idea of granting copyright to the director of an audiovisual product, civil scientists lost the unanimity of opinions when solving the issue of the theatre director's rights.

For example, one group of researchers insisted that the creative character of the work of the theatrical show director does not cause any doubt. The theses about the importance of the director's role in bringing the play to the public were given as the arguments. Besides, the representatives of the juridical community studied the history of theatre and stated that there are well-known cases when the play got widely known only thanks to its creative interpreting by the stage director.

Article 1313 of the RF Civil Code did not reconcile the antipodal opinions of the doctrine: the work of the stage director of a theatrical show, as well as the work of the director of an audiovisual product, is creative work. Correspondingly, a conclusion can be made that as far as the activity of the theatre director is not fixed in a form that would allow for its reproducing, the legislator has granted him only with the right neighboring to copyright.

Despite this, in the opinion of A. P. Sergeev, stage directors can only nominally be deemed to be performers [17, p. 150]. Different categories of performers vary in the content of their creative activities and in the degree of their involvement. If creative activities of actors-performers and conductors imply their personal participation in the artistic process, then the specificity of the stage director's work does not mean anything of the kind $[9$, p. 30].

Thus, when determining the circle of authors of an audiovisual product, the legislator (as E. P. Gavrilov was right to note) is guided by the fact that the "triumvirate" of the authors made a significant contribution to creating the product in question [4]. And as there is no any objective form demonstrating the result of a theatrical show director's work with regard to the artistic credo and the complex of the visual elements, the director is treated as a performer and appears to be a subject of neighboring rights.

The content of creative work of a theatrical show director is in uniting the creative efforts of a big team of "artists". The stage director begins when artistic chords arise out of several images, making up the symphony of the play [4].

However, in the legislator's opinion, their nonreproducibility is a key thing in distinguishing between the statuses of directors creating a show and those creating an audiovisual product. This criterion can be acknowledged as a sound one with a high degree of conditionality: the development of technology and the opportunity to fix directors' work when preparing the show and presenting it to the public (e. g. via video-recording) resolve the formal difference between the two subjects under consideration. Civil scientists have expressed completely opposite opinions on that.

For example, B. S. Antimonov thought that reproduction of a performance would remove the formal restriction in the form of the absent copyright object [1, p. 155]. M. V. Gordon insisted that there is no special copyright held by the theatre or the theatre director [5, p. 122]. In case of a reproduction, the author of the play is still the author of the literary script. With this, many authors note that an additional consent from the author is necessary for the recording, because the process of staging does not imply video-recording.

In our opinion, professional recording of performances, which is used for live broadcasting or for demonstrating it as a finished product, generates an independent object of copyright - an audiovisual piece of work. And as far as the specific characteristic of the theatrical activity is in performing live, then mechanical reproduction relieves the formal problem but not the contextual one.

\section{Legislative Regulation of the Theatrical Production Director Status in Russia}

The RSFSR Civil Code of 1964 contained Article 486, which was the first to regulate copyright to motion pictures, TV films, radio and TV programs ${ }^{1}$. Copyright was granted to production directors of motion pictures and TV films, and also to other authors whose products formed the constituent parts of the motion picture or the TV film.

\footnotetext{
${ }^{1}$ Civil Code of the RFSRS (approved by the RSFSR Supreme Soviet on June 11, 1964). [Electronic resource]. Accessed from reference legal system "ConsultantPlus".
} 
The basic legislative principles of the union of SSR and the republics ${ }^{1}$ introduced the category of neighboring rights, having given a legal status to the performance and having stated that actors, conductors and stage directors hold the right to their names, to protection of the show and the performance against misinterpretation, the right to make shows and performances and to authorize their usage, the right for remuneration.

Federal Law "On Copyright and Neighboring Rights" ${ }^{2}$ finally distinguished the stage director as the subject of copyright and neighboring right, recognizing the stage director as the author of an audiovisual product and the performer. Article 36 of the above law contained a rule according to which the director gave a permission to use the performance, along with the other performers or authors of the products to be used.

Article 1225 of the current edition of Part 4 of the RF Civil Code contains an exhaustive list of protected intellectual property results and individualization means, including the act of performing. Codifying relations in the sphere of the intellectual property, the legislator was committed to enlarging the RF Civil Code Chapters. This circumstance also influenced the theatrical performance - when Part 4 of the RF Civil Code was adopted, there were introduced the categories "theatrical production" and the "complex object", which replaced the earlier used "theatrical performance".

Some specific historical features, late reinforcement of the director's status and so on have become the reasons why the director is not covered with copyright. One more reason is uniting all the spectacular-type arts, starting from synthetic forms (a circus performance), where nominally there can be a director, but he is not systemically important, and finishing with a theatrical production, where the director enjoys the status of the first among equals. As a natural result, the rights of the director are protected within the neighboring right institution.

\footnotetext{
${ }^{1}$ Fundamentals of Civil legislation of the Union of SSR and the Republics: Approved by the Supreme Soviet of the USSR on May 31, 1991 No. 2211-1 (as amended on January 26, 1996). Gazette of the Congress of People's Deputies and the Supreme Soviet of the USSR. 1991. June 26. (No. 26).

${ }^{2}$ On Copyright and Neighboring Rights: RF law dd July 9, 1993 No. 5351-1 (as amended on July 20, 2004). [Electronic resource]. Accessed from reference legal system "ConsultantPlus".
}

In accordance with Article 1313 of the RF Civil Code, the stage director of a show is considered to be a performer, and the result of his creative work, the theatrical show, - to be performance. Thus, the result of an actor's, conductor's, director's activities has no difference and in all cases is deemed to be performance.

According to Article 1315 of the RF Civil Code, performers hold the right of authorship, right to name and to integrity of the product, and also the exceptional right. The exceptional right of performers is described in detail in Article 1317 of the RF Civil Code. It is exhaustive for actors and conductors, but for directors, due to the specific character of their activities a wider interpretation is needed. This circumstance fell under notice of the Russian legislator.

A group of activists headed by P.V. Krasheninnikov introduced to the State Duma a draft law proposing to enhance the protection of directors' rights $^{3}$. The authors specially focused on the following circumstances: a theatre director has no intellectual rights to the public "live" staging of the show; there are many situations in practice when directors' stage productions are actively used by other individuals with no prior consent from the directors ${ }^{4}$.

A theatre director, unlike an audiovisual product director, has no effective mechanisms of his right exercising and protection; however, the analysis of the innovations to be introduced into the RF Civil Code on January 1, 2018 with Federal Law of March 28, 2017 No. 43-FZ 5 shows that changing the concept of performing and formal granting the director with a wide range of rights, do not solve all the problems.

In defining the status of a theatre director, Soviet civil science proceeded from defining the theatrical performance itself. This problem has not been solved by the Russian legislator, and the hierarchy of performers established since January 1, 2017 in Article 1313 of the RF Civil Code looks as follows: an actor, a conductor, and a director. Such a rearrangement, in our opinion, does not solve important

\footnotetext{
${ }^{3}$ Cited from: Chronicles of the State Duma Session dd March 17, 2017. Available at: http://api.duma.gov.ru/api/transcript Full/2017-03-17 (accessed 31.08.2017).

${ }^{4}$ The same.

${ }^{5}$ About Introducing Changes into Part Four of the Russian Federation Civil Code: Federal Law dd March 28, 2017 No. 43-FZ [Electronic resource]. Accessed from reference legal system "ConsultantPlus".
} 
practical tasks, but indirectly underlines the isolated status of the director as compared to other performers.

Subitem 4 of Item 1 of Article 1315 of the RF Civil Code extends the right to integrity of the performance to the result of the director's creative activities. Correspondingly, staging stops to be the synonym of performance. The result of activities of the neighboring rights holders appears as follows: performance appears to be the result of actors' and conductors' activities, staging - of directors' activity.

We think that the given changes intensify the differences in the legal status of the director and other subjects of rights to performance: the legislator abandoned the existing unified approach to the objects of performance, not distinguishing the new results of performance in a proper way. "The right to performance integrity, including integrity of staging" - does it mean that staging is a variant of the performance?

Subitem 4 of Item 1 of Article 1315 of the RF Civil Code introduces a director's new right to public performance of the staging of the show. "The legislation in force does not give a theatre director intellectual rights to a public "live" staging of the show", - the initiators of changing the directors' status conclude. It was one of the reasons for updating paragraph 2 of Chapter 71 of the RF Civil Code.

As the new version of Article 130 of the RF Civil Code has it, a staging should have the following features: be a result of creative work, have the form of expression allowing for its repetition and distribution via technical means, and one more form of expression allowing for a repeat public demonstration while preserving the specific performance recognizability by viewers.

However, it has been mentioned in literature that the theatrical staging does not allow for its precise repetition even with the same team of actors and scenes [18, p. 54]. The absence of the multiple repetition of the performing activities results (including the staging) has formed a dominating opinion in the doctrine that each performance (staging) is a separate object and should be protected accordingly [3, p. 219].

The new form of expressing the staging established by the legislator allows for a conclusion that a theatrical staging is radically different from other results of performing activities: it allows for a multiple repetition, and so each subsequent perfor- mance recognizable for the viewer does not create a new neighboring right object for the director. In this respect, one issue which has not been solved so far is about the moment when a staging becomes a neighboring right object and the moment when the director's intellectual rights arise.

It goes without saying that the creation of a staging is an event; but does this object require a public performance? The provisions of the two articles of the RF Civil Code do not allow one to definitely answer the question: a staging is expressed in a form that allows for a repeat public performance (Subitem 1 of Item 1 of Article 1304 of the RF Civil Code), the exceptional right of the stage director is reserved during all his life, but no less than 50 years starting from January 1 of the year following the year when the first public performance took place (Item 1 of Article 1318 of the RF Civil Code).

At the same time the changes introduced into the content of the right to integrity (Article 1315 of the RF Civil Code) and the content of the exceptional right (Article 1317 of the RF Civil Code) allow us to suggest that the director's staging as a neighboring right object and intellectual rights themselves precede the first public performance.

\section{Conclusions}

The problem of defining the status of the director of a theatrical production is classical for the national civil science. For a long period of time, scientists have been comparing the audiovisual product as a copyright object and the theatrical performance. In both cases, the nature of the director's activities is creative, however the absence of the objectified result does not allow for recognizing the director as an author of a theatrical production.

At the same time, the director occupies a special position in the system of performers as holders of neighboring rights: the result of his creative work is reproducible, and his contribution to the creation of the general artistic conception of the show is essential. That is why the focus of the national legislator on enhancing the protection of neighboring rights of directors deserves positive evaluation. At the same time, many fundamental issues still need a detained legislative regulation: the definition of the theatrical production, differentiation between performance as the result of actors' and conductors' activities and staging as the result 
of the director's activities; determining the moment when the theatrical production becomes a result of intellectual activity and the moment when the director gets the right to this result.

\section{References}

1. Antimonov B. S., Fleyshits E. A. Avtorskoe pravo [Copyright]. 1957. 280 p. (In Russ.).

2. Bliznets I. A., Leont'ev K. B. Avtorskoe pravo $i$ smezhnye prava: uchebnik; pod red. I. A. Bliznetsa [Copyright and Neighboring Rights; ed. by I. A. Bliznets]. 2011. 416 p. (In Russ.).

3. Gavrilov E. P. Kommentariy k zakonu ob avtorskom $i$ smezhnykh pravakh [Commentary on the Law of Copyright and Neighboring Rights]. 2003. 212 p. (In Russ.).

4. Gavrilov E. P., Eremenko V. I. Kommentariy $k$ chasti chetvertoy Grazhdanskogo kodeksa Rossiyskoy Federatsii (postateynyy) [Commentary on Part Four of the Civil Code of the Russian Federation (Article by Article)]. Access from the legal reference system ConsultantPlus. (In Russ.).

5. Gordon M. V. Sovetskoe avtorskoe pravo [Soviet Copyright Law]. 1955. 232 p. (In Russ.). Grazhdanskoe pravo: uchebnik; pod red. A. P. Sergeeva, Yu. K. Tolstogo [Civil Law. Textbook; ed. by A. P. Sergeev, Yu. K. Tolstoy]. Vol. 3. 2011. 798 p. (In Russ.).

6. Grishaev S. P. Smezhnye prava [Neighboring Rights]. Access from the legal reference system ConsultantPlus (In Russ.).

8. Dozortsev V.A Intellektual'nye prava. Ponyatie. Sistema. Zadachi kodifikatsii. Sbornik statey [Intellectual Property Rights. Concept. System. Problems of Codification: Collection of Articles]. 2003. 416 p. (In Russ.).

9. Eremenko V. I. O pravovoy okhrane smezhnykh prav $v$ Rossiyskoy Federatsii [On the Legal Protection of Neighboring Rights in the Russian Federation]. Zakonodatelstvo i ekonomika - Law and Economics. 2012. No. 2. Pp. 30-55. (In Russ.).

10. Ionas V. Ya. Proizvedeniya tvorchestva v grazhdanskom prave [Works of Art in Civil Law]. 1972. 168 p. (In Russ.).

11. Istoriya russkogo dramaticheskogo teatra; pod red. Yu. A. Dmitrieva, T. M. Rodinoy, $O$. M. Fel'dman i dr. [History of Russian Drama Theatre; ed. by Yu. A. Dmitriev, T. M. Rodina, O. M. Fel'dman et al.]. Vol. 2. 556 p. (In Russ.).

12. Kommentariy k Grazhdanskomu kodeksu Rossiyskoy Federatsii (uchebno-prakticheskiy, postateynyy); pod red. S. A. Stepanova [Commentary on the Civil Code of the Russian Federation (Article by Article); ed. by S. A. Ste- panov]. Parts One, Two, Three and Four. Ekaterinburg, 2009. 1504 p. (In Russ.).

13. Kommentariy k Grazhdanskomu kodeksu Rossiyskoy Federatsii chasti chetvertoy (postateynyy); otv. red. L. A. Trakhtengerts [Commentary on Part Four of the Civil Code of the Russian Federation (Article by Article); ed. by L. A. Trakhtengerts]. 2009. 897 p. (In Russ.).

14. Korchagina N. P., Morgunova E. A., Pogulyaev $V . V$. Kommentariy $k$ chasti chetvertoy Grazhdanskogo kodeksa Rossiyskoy Federatsii (postateynyy); pod red. V.V. Pogulyaeva. [Commentary on Part Four of the Civil Code of the Russian Federation (Article by Article)]. Access from the legal reference system ConsultantPlus. (In Russ.).

15. Kotenko E.S. Avtorskie prava na mul'timediynyy produkt [Copyright to Multimedia Products]. Moscow, 2013. 124 p. (In Russ.).

16. Liptsik D. Avtorskoe pravo i smezhnye prava [Copyright and Neighboring Rights]. 2002. 257 p. (In Russ.).

17. Sergeev A. P. Intellektual'naya sobstvennost' [Intellectual Property]. 2000. 400 p. (In Russ.).

18. Serebrovskiy V.I. Voprosy sovetskogo avtorskogo prava [Issues of Soviet Copyright]. 1956. 283 p. (In Russ.).

\section{References in Russian}

1. Антимонов Б. С., Флейшии Е. А. Авторское право. М.: Госюриздат, 1957. 280 с.

2. Близнеи И. А., Леонтьев К. Б. Авторское право и смежные права: учебник / под ред. И. А. Близнеца. М.: Проспект, 2011. 416 с.

3. Гаврилов Э. П. Комментарий к закону об авторском и смежных правах. 3-е изд., М.: Экзамен, 2003.

4. Гаврилов Э. П., Еременко В. И. Комментарий к части четвертой Гражданского кодекca Российской Федерации (постатейный) [Электронный ресурс]. Доступ из справ.правовой системы «КонсультантПлюс».

5. Гордон М. В. Советское авторское право. М.: Юрид. лит. 1955. 232 с.

6. Гражданское право: учебник / под ред. А. П. Сергеева, Ю. К. Толстого. М.: Проспект, 2011. Т. 3.798 с.

7. Гришаев С. П. Смежные права [Электронный ресурс]. Доступ из справ.-правовой системы «КонсультантПлюс».

8. Дозориев В. А Интеллектуальные права. Понятие. Система. Задачи кодификации: сб. ст. М.: Статут, 2003. 416 c.

9. Еременко В. И. О правовой охране смежных прав в Российской Федерации // Законодательство и экономика. 2012. № 2. С. 30-55. 
10. Ионас В. Я. Произведения творчества в гражданском праве. М: Юрид. лит. 1972. $168 \mathrm{c}$.

11. История русского драматического театра / под ред. Ю. А Дмитриева, Т. М. Родиной, О. М. Фельдман и др. М: Искусство, Т. 2. $556 \mathrm{c}$.

12. Комментарий к Гражданскому кодексу Российской Федерации (учебно-практический). Части первая, вторая, третья, четвертая (постатейный) / под ред. С. А. Степанова. 2-е изд., перераб. и доп. М.: Проспект; Екатеринбург: Ин-т частного права, 2009. 1504 с.

13. Комментарий к Гражданскому кодексу Российской Федерации части четвертой (поста- тейный) / отв. ред. Л. А. Трахтенгерц. М.: Контракт: ИНФРА-М, 2009. 897 с.

14. Корчагина Н. П., Моргунова Е. А., Погуляeв B. B. Комментарий к части четвертой Гражданского кодекса Российской Федерации (постатейный) / под ред. В.В.Погуляева [Электронный ресурс]. Доступ из справ.правовой системы «КонсультантПлюс».

15. Котенко E. C. Авторские права на мультимедийный продукт. М.: Проспект, 2013. 124 с.

16. Липциик Д. Авторское право и смежные права. М.: ЮНЕСКО, 2002. 257 с.

17. Сергеев А. П. Интеллектуальная собственность. М.: Юрист, 2000. 400 с.

18. Серебровский В.И. Вопросы советского авторского права. М., 1956. 283 с. 